\title{
ROLE OF CO-OPERATIVE SUGAR FACTORIES IN RURAL DEVELOPMENT : A CASE STUDY OF DAMAJI SUGAR FACTORY, MANGALWEDA
}

\section{TODKARI G.U.}

Dept. of Geography, Shri Sant Damji Mahavidyala Mangalweda, Dist-Solapur, MS, India.

*Corresponding Author: Email- govindtodkari@gmail.com

Received: December 21, 2011; Accepted: January 12, 2012

\begin{abstract}
Sugar industry occupies an important position on the industrial map of the state of Maharashtra. These factories played a major role in the socio-economic development of rural areas in Maharashtra. The growth of various urban centers is helping to solve the problem of unemployment by providing employment in the growing industries and business. For the present investigation Damaji co-operative Sugar Factory is selected. Mangalwedha is located in drought prone area but Bhima river flows in these region. The Bhīma river catchment are favorable for sugar cultivation. Remaining drought area is large than irrigation area, drought area sugar factory become key factor of development and employment. In this investigation primary and secondary data are used. Such type of study represents real the role of co-operative sugar factory in rural of Mangalwedha and helps to planners, agricultural scientists and research scholars.
\end{abstract}

Key words - health camps, economic activities, beautification, social responsibility, Agricultural family

Citation: Todkari G.U. (2012) Role of Co-operative Sugar Factories in Rural Development : A case study of Damaji Sugar Factory, Mangalweda. International Journal of Agriculture Sciences, ISSN: 0975-3710 \& E-ISSN: 0975-9107, Volume 4, Issue 1, 2012, pp-168-171.

Copyright: Copyright@2012 Todkari G.U. This is an open-access article distributed under the terms of the Creative Commons Attribution License, which permits unrestricted use, distribution, and reproduction in any medium, provided the original author and source are credited.

\section{Introduction}

The sugar factories being agro-based processing units, are located near the supply of raw material namely sugarcane. These industrial units get located mainly in the rural areas and at tahsil or district centers. With the location of these processing units in the rural areas it is visualized that these factories can be the most appropriate agents for bringing about rural industrialization and change. The agro-based sugar factories with active Government aid and encouragement led to industrial dispersal in the state like Maharashtra. Along with dispersal of industrialization these factories due to their linkage effects became the growth centers for rural development.

Sugar co-operative for their expansion gave importance to better sugarcane production, supply of appropriate agricultural inputs to farmers and increased irrigation facilities in their area of operation. In addition growth of educational facilities, medical facilities, etc. were also undertaken as a part of area development by these cooperatives sled to growth of ancillary units, like paper plants, distillery units etc. which in turn increased employment and led to further industrial development in the rural areas. The success of sugar co -operatives in their commitment to area development led to growth of other agro-based processing units like dairy co-operatives, spinning mills, fruit processing units and such agro based industrialization helped in the development of agriculture and brought about the necessary transformation of the rural areas and in the process the benefits of these activities reached the farmers and they too benefited and progressed. Such process of rural transformation and change is very noticeable in western Maharashtra and more so in Solapur district where the co-operative sugar factories have indeed become the 'Growth Centers' for rural development.

\section{Objectives}

- To asses the employment opportunity in sugar factories.

- To illustrate the role of co-operative sugar factories in rural development.

- To suggest the recommendation for the development of sugar factory.

\section{Study area}

'Shri Sant Damaji Co-operative Sugar Factory, Mangalwedha' is situated in northern side of Mangalwedha city. Shri Sant Damaji Co -operative Sugar Factory Ltd Mangalwedha has started its first 
crushing season on 10th June, 1991 with low producing and crushing capacity. It is bordered by the Pandharpur tahsil on the whole of the northern side, by the Bathan on the east by the Bharmapuri on the south -east and Mangalwedha city on the south by the Sangola tahsil on the west. The study region i.e. Mangalwedha tahsil is one of the tahsil of Solapur district. It lies between $18^{\circ}$ North latitude and $76^{\circ}$ East longitude. The total area of the study region is about 1141.13 sq.km. Which is 7.62 percent of the Solapur district, consist of eighty one villages. According to geographical area, Mangalwedha tahsil is tenth number tahsil in Solapur District.

\section{Database \& Methodology}

For the present investigation primary data and secondary data are used. The primary data is collected through interviews, schedule and questioners. The secondary data are collected from annual sugar factory report and Damaji Sugar Factory Office. The collected data are represented by using various statistical and cartographic techniques.

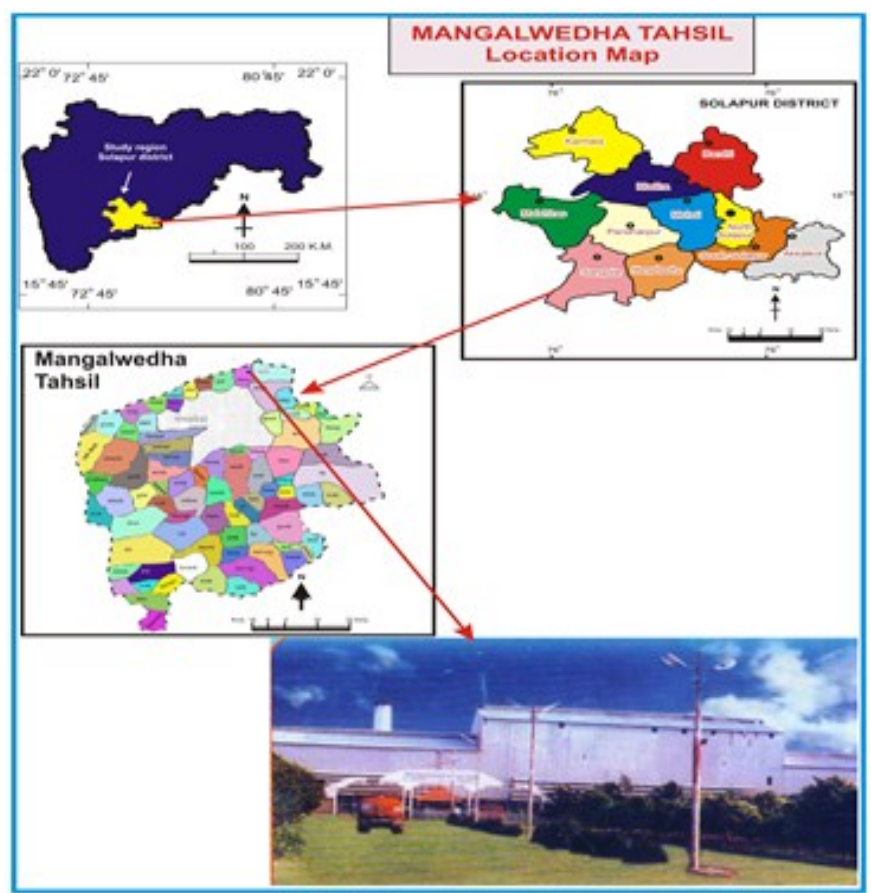

\section{Finding \& Discussion}

The co-operative sugar factory is established in a rural setting it becomes possible for the organization to help generate various ancillary activities for the benefit of local farmers and other member of rural society. Sugar co-operative provides the basis for organization other economic activities such as modern poultries, dairies, irrigation schemes, banks, goober gas plants, better breeding of cows and many other such activities which contribute largely to the betterment of the economic conditions not only of the farmers but also landless labourers and other people in the area. The factory also establishes school, heath centers for medical facilities with modern hospitals and dispensaries and organizes various cultural and sports activities. A considerable amount is set apart by many co-operative factories to make the life of the local inhabitants more purposeful and meaningful. Thus diversification of production activities leads to a process of rural industrialization which also is employment generating.
Lift Irrigation Scheme-The Shree Sant Damaji Co-operative Sugar Factory Ltd Mangalwedha has sponsored the lift irrigation schemes with a view to increase the land under sugarcane and to fulfill the needs of basic raw material, i.e. sugarcane within the command area. Lift irrigation schemes is in the area are formed mainly due to the keen interest shown by co-operative sugar factory gives guarantee to the banks for extending loans for irrigation schemes.

Development of Sugarcane- Crushing capacity of the factory is 2500 metric tones. As factory crushing season is of 223 days there is necessity of 600000 metric tones of sugarcane for good quality and high production of sugar. In working field and the variety of seedling used are Kosi 671, Co 94012, Co 86032 and the VSI 434, VSI 435 etc produced by tissue culture technology by company VSI for per acre increment in sugar production. These different programmes are organised by factory for the farmers.

Supply of Good Quality Sugarcane Seeds-The factory has been supplying the standard seed of sugarcane on its own cost to cane producer. The sugarcane seed is brought from famers. Similarly, the supply of seeds is also made available on credit from the seed plots of the other producers. Factory has supplied various types of sugarcane seeds i-e CO 671, Co 86032, to the member farmers. The Shri Sant Damaji Co-operative Sugar Factory has supplied sugarcane seed to farmer members. After the year 2005 more and more farmers have taken the benefits of cane seeds. From the year 2005-06 sugar factory expend 2 lakhs on cane seed programme. And in the year 2006-07 factory expand 1.54 lakhs on sugarcane seeds. In recent year more farmers have taken benefit of sugarcane seeds.

The beautification of factory site- From last one and half years nearly 1700 trees have been planted not only to control pollution but also to give shadow of love to members. It includes different types of Mango ,Nilgiri, Alphonso, Ashoka along with it coconut, and Chikku etc. cash trees also planted. For the beautification of the campus various trees are planted e.g. Tamarind, Bottle palm, Chapa, Silver oak, Gulmohor etc. The Golden Duranda is grown on 3500 feet on the factory site to decorate the campus.

Accident Insurance for factory members- The factory has made resolution in its meeting accident insurance for the members nearly 14240 members insurance would be the beneficiary of it. Nearly fourteen members have got benefit of this accident insurance. Life Insurance Corporation of India is providing these facilities to factory.

Helping hand to heirs of martyr- Out of social accountability, the factory used to help to the heir of the martyr, who dies on the border of the nation. The help is in the form of money. The amount is up to 1 lakh. This help is not only given to factory members but given to them also, who are not member. The factory has donated to Mukhyamantri Sahayyata Nidhi for earth quake affected people. In the year 2000-01factory funded 100000 to Government.

Agriculture exhibition To give advanced knowledge and information of agricultural to the farmers, factory used to organize agri- 
culture exhibition each and every year on the factory site. In this exhibition different stalls are installed e.g. agricultural technology, advanced equipments, fertilizers, seeds, animal husbandry, various government schemes etc. Many farmers visit and implement the things in their farms.

Computer Training to employees- In the 21 century, every thing is computerized. Hence the factory has arranged of the facility of computer training to the officers and other workers. Today more than 300 officers and workers are computer literate.

Cattle Camp- The factory has started the camp for the cattle's belonging to drought stricken area of the factory. Out of social responsibility the factory has started cattle camp on 2 Sept. 2003 to save live stock. It was run for 10 months and almost more than 2000 cattle's were kept in the camp. Factory expands 25 lakh on these cattle camp.

Shopping centre- In the age of IT competitor the question of employment became very severe in front of the rural youth also. The factory has decided to build shopping centre and make it available to the unemployed rural youth. It will help the rural youth for get the work to their hands.

The safe of fruit-bearing trees to farmers- To improve the financial condition of the farmers, the factory has started the scheme of providing the fruit - bearing trees to the farmers. This scheme was started in the year 2002-03. In the year 2002-03 factory had supplied 1120. Fruit plants on no profit and no loss basis and the cost of plants was Rs15590. In the year 2004-05 farmers took 515 fruit plants from the factory the cost of which was Rs7770. After the year 2004-05 the number of fruit plants supplied has increased. Thus the Shri Sant Damaji Co-operative Sugar Factory is making its attempts to develop fruit plantation and thus increase the greenery in its area of its area of operation.

Sugar distribution to members- The factory Board of Director decided to distribute sugar to the members 5 kilograms per year on concessional rate.

Sugar Factory School- The sugar school is started near factory site with the help of sugar commission for the children of sugarcane cutter labours. Factory gives the training to teachers in collaboration with 'Aastitva prakashan' Pune. Factory provides all the educational aids to all the children which are admitted in the sugar factory school. In the year 2006-2007, 150 children get benefits of it.

Felicitation of Meritorious students- The students who embark their names in Merit list of H.S.C. and S.S.C. exams belongs to Agricultural family. These students are felicitated by factory every year. The factory used to give inspiration to the meritorious students by felicitating them.

Response to emergencies- During emergencies and natural calamities the resources of the factory prove extremely useful for organizing relief and other activities. On all such occasions the leaders and shareholders have contributed generously. The Gov- ernment department have now realized the importance of the factories in the life of the local people and have there for been relying increasingly on their help and co-operation. It is such easier and more effective on mobilize people for relief work when the leaders and shareholders voluntarily decide to do so instead of on the diktat of a Government official.

Supply of Molasses- Molasses has become a very valuable raw material for the chemical industry. It is also used as fertilizer into field as well as for the burning coke. Molasses is a good for the fields growing sugarcane. .In the year 2000-01 farmers had taken 22500 tones of molasses. The rate of molasses was Rs. 1333.33 per tone. In the year 2006-07 farmers took 20444.760 tones of molasses and the rate was Rs 2006 per tone. The molasses is used for fuel purpose and also as manure in the farms.

Road Construction- Efforts have been made by the sugar factory for the development of roads. This process has helped to build up infrastructural facility in the rural areas. For accelerating the transport of harvested cane to factory from the fields, the sugar cooperative has built up approach road in its area of operation. Sugar factory has been constructing cross ways across the river and streams by using home pipe to reduce the distance between the factories and the area of harvesting. Government grants are made available to the factory to make use of the bulldozers for road leveling purpose. As a result of these efforts made by the sugar factory, the sugar factory in turn gets the benefit of the higher recovery of harvested cane duke to quick transportation of cane to the factory for crushing. The above table gives details of the expenditure of road construction. In 2006-07, there was Rs 18000 expenditure on road construction and in the year 2006-07, Rs 27000 expenditure was incurred on road construction. Shri Sant Damaji Co-operative Sugar Factory Ltd., Mangalwedha has built up some approach roads in the area of operation as below.

Labour Welfare Programme- There is good relation between workers and the management from the inception of the cooperative sugar factory. Factory is always ready to solve all labour problems. Sugar factory sends the workers for training and seminars. The facilities of indoor and outdoor games have been provided by the Shri Sant Damaji Co-operative Sugar Factory. These activities include volleyball, carom, chess, table tennis, cricket etc. The factory canteen is run on private basis. Tea, Snakes, meals etc., are served in the canteen. Factory has established a good modern colony on factory site for workers and their family members. One health centre is in the premises of the factory with a qualified Medical Officer and requisite staff. All workers of the factory and their family and harvesting workers are giving medical treatment of concessional rates. Library facility with book of well known writers is available for the workers and families residing at the factory site. The dailies, and Magazines which are widely popular in Maharashtra are made available for reading purpose and the workers take the benefit of it. It is the factory's pride and honor that the marginal amount of bonus ( 20 percent) are paid to the factory workers.

Medical Facility- The Shri Sant Damaji Co-operative Sugar Factory organized camps. The factory organizes health camps for vari- 
ous diseases of the eye, teeth, skin, child health, cancer etc. In these camps expert doctors in the respective fields are called and the treatment is given free of charges to the patients. If needed operations are done and some cast is borne by the co-operative sugar factory. In the year 2001 to 2007 these camps were organized and 4030 persons took benefit of the facility

\section{Conclusion}

Shri Sant Damaji Co-operative Sugar Factory is situated in Uchethan and established in 1991. This sugar factory is affected on catchment area with various ways. Various schemes have adopted by sugar factory for the surrounding rural area development. In which Agriculture exhibition, Computer Training to employee, Cattle Camp, Felicitation of Meritorious students, Response to emergencies, Supply of Molasses, supply of good quality sugarcane seeds, Accident insurance, Sugar factory school, Labour Welfare programs etc. are included. But cogeneration and distillery project are not started in this factory which can give large profit and create more employment opporchnity.

\section{References}

[1] Annual Report of Shri Sant Damaji Co-operative Sugar Factory Ltd., Mangalwedha.2009/10

[2] Mohite.Y.J. Sugar Industry in Maharashtra.

[3] Bhanje B.M. (1995) Sugar Co-operative And Rural Transformation. A Geographical Perspective of the Command Area of Warana Sugar Factory', Unpublished Ph.D. thesis, (Geography) Shivaji University, Kolhapur.

[4] Inamdar N.R. (1973) Government and Co-operative Sugar Factory.

[5] Singh G.B. (1979) Transformation of Agriculture.

[6] Das B.N. and Sarkar A.K. (1972) Rural area Development Karnal Area.

[7] More K.S. (1980) Changing Pattern of Agriculture Landaus In Kolhapur District (Maharashtra)' unpublished Ph.D thesis, Shivaji University, Kolhapur. 